УДК 94: 329.15] (477. 82) “1989”

30-річчю фестивалю "Червона Рута" в Чернівцях присвячується

\title{
ФЕСТИВАЛЬ “ЧЕРВОНА РУТА” 1989 р. У ВІЗІЇ ЧЕРНІВЕЦЬКОГО ПАРТАПАРАТУ
}

\author{
Василь ЧУРА \\ Львівський національний університет імені Івана Франка, \\ кафедра історичного краєзнавства \\ вул. Університетська, 1, Львів, 79000, Україна \\ e-mail: vchbox@ukr.net
}

\begin{abstract}
Наукова розвідка ілюструє рецепцію в Чернівецькому обласному комітеті КПРС-КПУ та його структурних підрозділах розгортання національно-демократичного руху і культурного відродження української патріотично налаштованої громадськости Буковини на тлі перебудовних новацій у СРСР другої половини 80-х - початку 90-х рр. ХХ ст. Помітним зразком національнокультурного ренесансу Буковини стало проведення в Чернівцях у 1989 р. пісенного фестивалю “Червона Рута", який став ілюстратором трансформації загальнодемократичних вимог у національні заклики, а відтак наштовхнувся на активну протидію місцевого партапарату.

Ключові слова: перебудова, компартапарат, неформальні товариства, національно-культурне відродження, музичний конкурс “Червона Рута", протидія.
\end{abstract}

Соціяльно-економічні негаразди, спричинені відсутністю приватної власности, та нестійкість політичної системи Радянського Союзу, що діяла за умов однопартійности у другій половині 80-х рр. ХХ ст. досить помітно розмивали підвалини регіональної компартійної влади. Це загрожувало монополізму правлячої КПРС, що й стало причиною запровадити комплекс політикоекономічних реформ, знаних як перебудова. Дозовані проросійським партапаратом демократизація, відкритість, гласність та плюралізм думок покликали до життя стрімке національно-культурне відродження в тих регіонах СРСР, які найпізніше увійшли до його складу й зберігали хоча й латентні, однак українські патріотичні настрої. До таких земель належала Буковина, що стала складовою частиною Союзу РСР у 1944 р., а значить, із народної пам'яті тут ще не було стерте українське національно-визвольне минуле. Як наслідок, економічні вимоги переросли в загальнодемократизаційні заклики, а згодом трансформувались в антикомуністичний рух, оскільки мали міцне місцеве коріння, попри строкатий етнічний склад цього регіону УРСР, що в адміністративній побудові носив назву Чернівецької области

Комплексний науковий аналіз розгортання локальних чинників, котрі стали передвісниками краху компартійної влади у Буковини на зламі 80-90-х рр. ХХ ст. в контексті національно-культурного ренесансу краю ще вимагає уваги українських істориків. Однак цей фактор не лише зумовив відродження 
ISSN 2078-6077. Наукові зошити історичного факультету Львівського університету. 2020. Випуск 21. Proceedings of History Faculty of Lviv University. 2020. Issue 21.

патріотичних настроїв, а й спричинив подальше утворення політичних партій, які поклали край осібному комуністичному пануванню та врешті дали змогу відновити державну самостійність України. Тому завдання цісї статті - вивчити зразки відродження української культури періоду перебудови та те, як їх сприймала локальна проросійська комуністична влада.

Фрагментарно порушеного питання торкалися В. Баран ${ }^{1}$, С. Кульчицький ${ }^{2}$, О. Муравський ${ }^{3}$, С. Кобута ${ }^{4}$, Я. Секо ${ }^{5}$. Джерельною базою наукової розвідки слугуватимуть неопубліковані, таємні матеріяли комуністичного справочинства, сторінки періодичних видань того часу та матеріяли польових досліджень.

Засвідчуючи “вирішення національного питання" в Чернівецькій області, перший секретар обкому М. Нівалов у травні 1989 р. переконував мешканців регіону у тому, що тут відсутнє етнічне протистояння, але домінує комуністична інтернаціональна політика. Як доказ наводилися такі приклади: для гармонійного розвитку двомовності за роки радянської влади в області створено 421 школу: 296 українських, 85 молдовських, 32 російських, 17 двомовних. У Чернівецькому державному університеті (ЧДУ) та Чернівецькому педагогічному училищі (ЧПУ) діяли катедри молдовської мови. У Чернівцях відкрито магазин молдовської культури “Лучаферул” (“Вечірня зірка”). Розглядалося питання переходу молдовських шкіл на латинську графіку. Молдовською мовою виходила обласна газета “Зориле Буковіней” (“Зоря Буковини”). У Чернівцях, Новоселицькому, Глибоцькому, Сторожинецькому районах планували відкрити п’ять молдовських шкіл, а в місті Герца Глибоцького району відкрито погруддя Г. Асакі та передбачено спорудити пам'ятник М. Емінескуб.

Проте, як свідчило вивчення таємних партійних документів, національні стосунки не були такі безхмарні. Їх значно загострювала алопеція - облисіння дітей та дорослих, спричинена необережним поводженням військовиків із хімічними речовинами. Спроби партапарату засекретити наслідки епідемії приводили до стихійних мітингів та посилювали недовіру мешканців регіону до комуністичної влади. Станом на 25 жовтня 1989 р. в області зафіксовано 895 скарг

${ }^{1}$ Володимир Баран, Україна: новітня історія (1945-1991 рр.), (Львів: Інститут українознавства імені І. Крип'якевича НАН України, 2003), 670.

${ }^{2}$ Станіслав Кульчицький, “Історичні передумови переростання перебудови в національну революцію (1989-1991),” Проблеми історії України: факти, судження, пошуки: Міжвідомчий збірник наукових працьь, № 5, (2001): 330.

${ }^{3}$ Олег Муравський, Західні землі Украӥни: шлях до незалежності (1985-1991), (Львів : Інститут українознавства ім. І. Крип'якевича НАН України, 2011), 268.

${ }^{4}$ Степан Кобута. "Неформальні” громадські організації у 1987-1989 роках як попередники українського політичного руху”, Наукові записки Тернопільського національного педагогічного університету імені Володимира Гнатюка. Серія: Історія, № 1, (2008): 125.

5 Ярослав Секо. “Нелегальні організації УРСР другої половини ХХ ст.: загальна характеристика", Украӥна-Свропа-Світ. Міжнародний збірник наукових праџь. Серія: Iсторія, Міжнародні відносини, № 5, (2012): 112.

${ }^{6}$ Чернівецький обком Компартії України, ДАЧО, ф. 1, оп. 60, спр. 154, арк. 13. 
невідомого хімічного захворювання. Як наслідок, 11 жовтня в обкомі партії відбулася зустріч матерів захворілих дітей, де пролунало 165 нарікань щодо замовчування та неспроможність партапарату контролювати ситуацію7.

Серед етнічних меншин Буковини спостерігався процес оформлення культурних товариств у непідконтрольні КПРС-КПУ спілки, що мали на меті відроджувати знівельоване комуністами національне самоусвідомлення. Соціяльною основою Спілки молдовсько-румунської культури імени М. Емінеску, утвореної 18 лютого 1989 р. в Чернівцях, були науковці, викладачі, студенти ЧДУ та ЧПУ, шкільні вчителі, представники громадських організацій і засобів масової інформації. Відтак, 19 лютого того ж року засноване Товариство єврейської культури імені Е. Штейнбарга при Українському фонді культури. Керівниками об'єднання були Л. Фінкель та 3. Браславський. Активісти проводили тематичні вечори 3 подальшим їх обговоренням на сторінках єврейської преси. Затим, 9 липня у Чернівцях відбувся мітинг, присвячений пам'яті євреїв, що їх розстріляли нацисти в 1941 р. біля р. Прут. В області діяли курси вивчення ідишу та івриту, факультативи єврейських мов у школах та відділ єврейської літератури в одному із книгарень магазинів Чернівців 9

У річищі розгортання українського національно-демократичного руху на теренах Буковини діяло 43 неформальних товариства, чотири госпрозрахункові центри молодіжного дозвілля, два клуби науково-технічної творчості. Чільними серед них були “Братерство”, “Діалог”, “Поліфах”, “Долг”, “Візит”, “Луч” що об’єднували понад три тис. учасників. Вони проводили політичні диспути, “круглі столи”, краєзнавчо-пошукові студії, екологічну акцію “Дністер-89”, конкурси “Чернівецька красуня”, “Фантазії і сучасність” “День молоді” тощо ${ }^{10}$.

До наймасовіших організацій, що концентрували патріотично налаштовану громадськість Чернівеччини, належало Товариства української мови імени Т. Шевченка (ТУМ). У 1988 р. під егідою місцевої філії Фонду культури СРСР проведено установчі збори спілки, котра взяла курс на відродження національних надбань українського народу в Чернівецькій області. Товариство очолювали О. Панчук та В. Старик ${ }^{11}$. За спогадами сучасників, зокрема голови осередку ТУМу Чернівецького меблевого комбінату О. Курніцького, члени товариства не мали підтримки парткомів, а навпаки - відчували з їх боку постійні утиски. Наприклад, директор підприємства О. Кубляк погрожував не надавати ТУМівцям матеріяльної допомоги, а парторг зірвав стіннівку “Рідне Слово” і передав iї в КДБ ${ }^{12}$.

7 Чернівецький обком Компартії України, ДАЧО, ф. 1, оп. 60, спр. 210, арк. 87.

8 Чернівецький обком Компартії України, ДАЧО, ф. 1, оп. 60, спр. 211, арк. 1

9 Чернівецький обком Компартії України, ДАЧО, ф. 1, оп. 60, спр. 211, арк. 21.

10 Чернівецький обком Компартії України, ДАЧО, ф. 1, оп. 60, спр. 314, арк. 23-24.

${ }^{11}$ Чернівецький обком Компартії України, ДАЧО, ф. 1, оп. 60, спр. 211, арк. 2-4.

${ }^{12}$ Олександр Курніцький. "Рідне слово,” Буковинський вісник, № 10, (1989): 1. 
ISSN 2078-6077. Наукові зошити історичного факультету Львівського університету. 2020. Випуск 21. Proceedings of History Faculty of Lviv University. 2020. Issue 21.

На думку першого секретаря міськкому В. Євдокименка, найнебезпечніша була місцева філія Української Гельсінської Спілки (УГС), якою керували В. Кузьмін і Д. Ганкевич. Ініціятивна група УГС нараховувала чотири особи активу та 250 рядових членів, які повернулися з місць позбавлення волі за націоналістичну пропаганду і агітацію ${ }^{13}$. Не викликала симпатій компартійного начальства і створена в ЧДУ “Спілка Незалежної Української Молоді Буковини” (СУМБ), котрою керував С. Солтус. СУМБ видавала нелегальні газети "Українська Справа" i “Смолоскип” та проводила націоналістичну роботу серед студентського та викладацького колективів університету ${ }^{14}$.

Такого ж негативного ставлення компартапарату заслуговували члени товариств “Зелений Рух Радянської Буковини” (керівники - Л. Сандуляк, Т. Блайко) та "Оберіг” (Я. Волощук), які “намагалися очорнити діяльність органів влади та контактували з антисуспільними елементами з інших областей”. До них приєднувалися "Фонд сприяння збереженню єврейських кладовищ" (I. Зісельс), "Науково-мистецький клуб”, група незалежних дослідників "Меморіял" (А. Галін, І. Мельничук, М. Кушнір) та літературна студія "Січ" (Г. Галиць, Ю. Поліщук). Партійні документи засвідчували: лідери названих організацій підтримували тісні стосунки з неформальними товариствами Львова, Кишинева, Таллінна, Москви, Ленінграда, а тому перебували в полі зору КДБ ${ }^{15}$.

Як наслідок, від 1989 р. лейтмотивом протоколів партійних форумів був острах місцевого партапарату, який засвідчував поступове звуження його політичної амплітуди. Цей процес засвідчив виступ професора ЧДУ, депутата Верховної ради СРСР Л. Сандуляка, виголошений на жовтневій партконференції. Звертаючись до компартійної номенклатури, він зазначав: “ЗЗ сімдесят років ви не вирішили ні економічної, ні національної, ні духовної, ні екологічної проблем. Людей не цікавить наскільки скоротилися ваші штати. Падіння авторитету Компартії - це факт"16.

Згортання політичної ваги КПРС добре ілюструвала нелегальна антикомуністична преса. Газета НРУ “Буковинський Вісник” у 1989 р. опублікувала 157 статтей, котрі закликали до боротьби з монополізмом правлячої партії. На шпальтах однієї з них О. Панчук, В. Кондратенко, І. Кравчук (всього 15 авторів) стверджували: “Є $Є$ дина антирадянська влада в Україні - це Комуністична партія, яка забрала владу у рад. Але реальна влада належить не усім 19 мільйонам партійців, а партноменклатурі, злочини якої не мають прощення" 17 .

\footnotetext{
${ }_{13}$ Чернівецький обком Компартії України, ДАЧО, ф. 1, оп. 60, спр. 210, арк. 18.

${ }^{14}$ Там само, спр. 314, арк.

${ }^{15}$ Там само, спр. 226, арк. 48-53.

${ }^{16}$ Там само, спр. 154, арк. 65-69

${ }^{17}$ Олег Панчук О. "Рух і вибори”, Буковинський Вісник, №12, (1989), 3.
} 
За таких обставин протидія комуністичної влади не змушувала себе довго чекати. Вона посилилася після публікації в газеті “Літературна Україна” від 17 лютого 1989 р. програми діяльности Народного руху за перебудову (НРУ) ${ }^{18}$. 12 розділів методичних матеріялів обкому говорили про таке. 1. Рух створено на основі вузькогрупових, корпоративних інтересів. 2. Його політичною метою $\epsilon$ втягування суспільства на в'язкий грунт шкідливих перманентних дискусій. 3. Програма дій $є$ альтернативною платформі КПРС, частково являється іiі плагіатом, має на меті контроль партійних організацій і фрагментарно взята із політичних документів УГС, УДС та “Саюдісу”. 4. Ряд положень програми НРУ не відповідають конституційним нормам СРСР: економічний суверенітет республік, народна власність, проведення всенародного референдуму. 5. Зміст програми носить утопічний характер і націлений на руйнацію політичного устрою країни. Заключна частина документу попереджала: кожен член партії, який закриє очі на спроби розпалити неприязнь до КПУ - отримає сувору оцінку ${ }^{19}$.

Відтак, 3-го квітня 1989 р. обком напрацював заходи противенства спробам націоналістів створити альтернативні КПРС політичні структури. На особливу увагу заслуговував їх шостий розділ. Органи УВС, КДБ, прокуратури та суду зобов'язувалося протидіяти утворенню осередків НРУ на підприємствах области, посилити інспектування діяльности його активістів, встановити контроль за реалізацією копіювальної техніки ${ }^{20}$. Дня 26 квітня 1989 р. секретарі обкому М. Іванеско та В. Васкан повідомляли: у всіх трудових колективах, парткомах та на сесіях районних рад народних депутатів відбулися зібрання, що засуджували створення НРУ. У ЗМІ оприлюднено 14 матеріялів, які дискредитували НРУ та національну українську символіку. ${ }^{21}$ Одну 3 них помістила газета Заставнівського райкому “Прапор Перемоги”. Директор місцевої школи, вчитель історії Г. Таран переконував читачів, що “тризуб та жовто-блакитний прапор стали символами політичних банкротів - бандерівських збройних формувань - лютих ворогів українського народу”"22.

У відповідь на політизацію громадських об'єднань Буковини липневий пленум обкому 1989 р. зазначав: серед неформальних організацій все більшого розголосу набирають відверто ворожі антикомуністичні і націоналістичні гасла. Має місце розповсюдження ідейно шкідливих листівок, що пропагують національну незалежність та символіку. Відбувається консолідація активістів львівської, тернопільської, івано-франківської та чернівецької філій УГС, проводяться спільні вуличні акції, ведеться обмін літературою та постачання копіювальної техніки. 3 цього приводу партапарат планував розкривати справжні цілі організаторів

\footnotetext{
18 Літературна Украӥна, 1989, 3.

19 Чернівецький обком Компартії України, ДАЧО, ф. 1, оп. 60, спр. 226, арк. 19-30.

${ }^{20}$ Там само, спр. 221, арк. 10

${ }^{21}$ Там само, спр. 226, арк. 31-32.

${ }^{22}$ Григорій Таран, “Про українську символіку”, Прапор Перемоги, №10, (1989), 2.
} 
ISSN 2078-6077. Наукові зошити історичного факультету Львівського університету. 2020. Випуск 21. Proceedings of History Faculty of Lviv University. 2020. Issue 21.

УГС, НРУ, ТУМу та СУМБу і закликав негайно позбавляти партійности членів неформальних організацій ${ }^{23}$.

Відтак, 8 серпня 1989 р. обком ухвалив таємну постанову ЦК КПУ “Про план заходів щодо оздоровлення суспільно-політичної обстановки, що склалася в результаті страйків в окремих областях республіки" та зобов'язав іï виконувати ${ }^{24}$. Партверхівка зобов'язувала переобрати ради трудових колективів та профспілки, наповнивши їх досвідченими комуністами, налаштованими на “конструктивний діялог”, протидіяти проведенню страйків та мітингів, не допускати заміни номенклатурних господарських керівників, протистояти проникненню в робітниче середовище екстремістів, запобігати публікаціям у ЗМІ провокативних матеріялів та неперевірених фактів, відпрацювати координацію дій органів МВС, КДБ, прокуратури, радянських інституцій та робітничих загонів для посилення охорони громадського порядку ${ }^{25}$.

Однак такі “превентивні” заходи партапарату не мали підтримки в місцевого населення, особливо молоді. Про це свідчило проведення пісенного конкурсу "Червона Рута", який вийшов з-під контролю партійного керівництва й сколихнув патріотично налаштовану громадськість Буковини. Він відбувся в Чернівцях 17-24 вересня 1989 р. та здійснив "революцію” в українській пісенній культурі, що українізаційно вплинула на усю молодіжну авдиторію УРСР. Фестиваль ініціював сучасну неформальну національну музику, яка до того існувала у зародку поза сценою. Внаслідок російсько-комуністичного панування, маючи недостатню кількість вітчизняних пісенних виконавців, українська молодь здебільшого задовольнялася московською естрадою або підпільно слухала західних зірок.

Ініціятором провести фестиваль став відомий український журналіст, дослідник творчости В. Івасюка - І. Лепша. 27 грудня 1987 р. у газеті "Молодь України” він опублікував статтю “То $є$ чистая вода...”, у якій загострив увагу читачів на відсутності пісенного конкурсу, де могли б змагатися виконавці, що не $€$ членами радянських мистецьких спілок. 3 того приводу він писав: “У зв'язку 3 таким становищем вношу пропозицію: проводити щорічний конкурс-фестиваль “Червона Рута", на якому звучали б у виконанні BIA (вокально-інструментальних ансамблів) та солістів естради нові твори як композиторів-професіоналів, так і композиторів-аматорів. На конкурсі-фестивалі "Червона Рута", який став би даниною пам'яті Володимирові Івасюку, тривала б і творча співпраця професіоналів з аматорами. Конференцію музичних діячів можна скликати у місті, де проводиться "Червона Рута"26.

Ініціятиву підтримали відомі українські діячі культури Д. Гнатюк, В. Зінкевич, Д. Павличко, Н. Матвієнко. На початку 1988 р. формат проведення фестивалю

\footnotetext{
${ }^{23}$ Чернівецький обком Компартії України, ДАЧО, ф. 1, оп. 60, спр. 154, арк. 12-15.

${ }^{24}$ Там само, спр. 163, арк. 14.

${ }^{25}$ Там само, спр. 163, арк. 39-43.

${ }^{26}$ Іван Лепша “То є чистая вода...”, Молодь Украӥни, № 9, (1987), 3.
} 
уклали музиканти К. Стеценко, А. Калениченко та поет I. Малкович, а його сценарій написала поетеса С. Майданська. Забезпечило музичну апаратуру українсько-канадське спільне підприємство “Кобза”, яким керували О. Репецький та Т. Мельник.

Щоб увести фестиваль у комуністичне русло та контролювати його проведення, компартійна влада офіційно назвала його Першим республіканським фестивалем сучасної української пісні “Червона Рута" та призначила організаторами ЦК ЛКСМУ, Міністерство культури УРСР, Українську республіканську раду професійних спілок, Держтелебачення УРСР, Спілку композиторів та письменників УРСР, Український фонд культури, Музичне товариство УРСР, Товариство культурних зв'язків з українцями за кордоном. На республіканському рівні організаційний комітет очолював секретар ЦК ЛКСМУ Ю. Соколов. Головою журі став секретар правління Спілки композиторів УРСР М. Скорик, відповідальним секретарем - В. Івченко, головним режисером - С. Проскурня, керівником дирекції - А. Горностай. Спонсорами були львівські ВО “Кінескоп”, “Електрон”, “Іскра”, тернопільське НВО “Ватра”, івано-франківська агрофірма "Прут”, українсько-канадське СП "Кобза", які асигнували 330 тис. крб. Відкривав фестиваль перший секретар ЦК ЛКСМУ А. Матвієнко 27.

Як засвідчило подальше розгортання подій, це було перше офіційне музичне свято в західних областях УРСР, яке не лише самопозбавилося партійного підпорядкування, але й стало поштовхом до значної активізації національновизвольного руху, що мав на меті відновити державну самостійність України. Після відбіркових конкурсів, що проводилися в усіх областях УРСР, до Чернівців з'їхалися понад 600 виконавців: 80 вокально-інструментальних ансамблів, 30 рок-груп та 50 виконавців авторської пісні. Серед них були такі знані в майбутньому піснярі-початківці, як І. Білик, М. Бурмака, В. Жданкін, В. Морозов, А. Миколайчук, А. Панчишин, Г. Тельнюк, Л. Тельнюк, Т. Чубай, музичні гурти “Брати Гадюкіни”, “ВВ”, “Кому вниз”.

Роботу висвітлювало періодичне видання "Червона Рута. Вісник фестивалю”, яке виходило під гаслом "Пролетарі усіх країн, єднайтеся!", що мало би підкреслювати комсомольский патронат конкурсу. Газета напрацювала сім чисел, накладом у п'ять тис. примірників, вартістю по 30 копійок. Номери готували головний редактор М. Лазарук, журналісти: Г. Бойчук, В. Ворон, В. Гриб, Ю. Луканов, В. Теремко.

Гран-прі здобув львівський виконавець В. Жданкін, лавреатами стали В. Морозов, Т. Курчик, А. Миколайчук, Е. Драч, О. Тищенко, В. Врадій, М. Бурмака, П. Дворський та колективи “ВВ”, “Кому вниз”, “Брати Гадюкіни”, “Мальви”, “Зимовий сад”. Серед дипломантів значилися О. Савчук, Т. Чубай,

\footnotetext{
${ }^{27}$ Андрей Федоров, “Каким цветом зацвела “Червона Руга”?”, Правда Украиныl, №10, (1989), 4.
} 
ISSN 2078-6077. Наукові зошити історичного факультету Львівського університету. 2020. Випуск 21. Proceedings of History Faculty of Lviv University. 2020. Issue 21.

Г. Тельнюк, Л. Тельнюк, І. Сітарський, О. Покальчук, О. Гаркавий, М. МузикаБеджанова, В. Свирід, Л. Улична, Л. Горова, Ю. Товстоган, С. Щербатих, I. Козаченко, В. Чинч та гурти “Аванс", “Край”, “Еней”, “Рутенія”, “Гуцули”, “Захід”.

Про небезпеки участи у фестивалі пригадував у інтерв’ю один із організаторів НРУ, інженер КБ ВО “Фотон” В. Старик. Він зазначав, що помітна роль у зміні вектора конкурсу із прокомуністичного на національний належала місцевим активістам УГС, НРУ, ТУМу, СУМБу, “Зеленого Світу”, до яких приєдналися члени львівського “Товариства Лева” та тернопільських й івано-франківських неформальних організацій. Серед їх акцій вирізнялися піші ходи в національному одязі із жовто-блакитною символікою, публічне виконання українських пісень i танців, вуличні дискусії із представниками влади, застосування декоративних конструкцій. Увагу глядачів привертала бутафорська гармата, яка щоразу “вистрілювала" комуністичної пресою.

Міліцейські загони за допомогою спеціяльних засобів розганяли зібрання, вилучали національну символіку, затримували активістів, за допомогою гучномовців заглушували виконання національних пісень, вимикали струм. Дійшло до того, що співачка М. Бурмака зі сцени була змушена закликати правоохоронців припинити безчинства. Показовий випадок трапився і $з$ членом журі T. Петриненком, якого мало не депортували з Чернівців за те, що він виконав незаплановану пісню про Народний рух України ${ }^{28}$.

За словами львівського співака В. Морозова, антиукраїнські акції міліції та КДБ обурили артистів і глядачів. Кожен день розпочинався і завершувався стихійними мітингами, спричиненими побиттям, обшуками й арештами людей у національному одязі, перериванням співу українських пісень, вилученням національної символіки. Тому під час заключного виступу ухвалено таку резолюцію: “Ми учасники “Червоної Рути” протестуємо проти брутальної акції, вчиненої органами КДБ і МВС з благословення міськкому партії’29.

Офіційне закриття фестивалю у повному обсязі фактично не відбулося. Наляканий перший секретар обкому партії М. Нівалов наказав припинити подачу струму. Як згадував згодом перший секретар обкому комсомолу П. Луців, фестиваль став великим клопотом для влади міста. Начальник обласного управління культури В. Королюк заявляв, що кінцевої мети фестивалю не досягнуто, а його щорічна регулярність $\epsilon$ "під великим знаком запитання". Заступник голови облвиконкому Г. Цуркан стверджував, що фестиваль був не конкурсом, а націоналістичним шабашем. Він звинувачував керівництво фестивалю у відмові співпрацювати з радянськими інституціями Чернівців, працівниками обласного та міського відділів культури, правоохоронними органами, а особливо в надмірному сприянні журі посланцям Львівської, ІваноФранківської та Тернопільської областей. Не залишалася осторонь і художня

\footnotetext{
${ }^{28}$ Інтерв’ю В. Старика записане 21. 07. 2010. (Особистий архів автора).

${ }^{29}$ Буковинський Вісник, (1989), 3.
} 
інтелігенція. Керівник Буковинського ансамблю пісні і танцю А. Кушніренко пророчив, що пісні “Братів Гадюкіних”, “Сестрички Віки” швидко забудуть, тому що вони $\epsilon$ не мистецтвом, а “дрібнотрав'яним політичним фарсом”зо. Від імени обласної влади до організаторів фестивалю надійшов лист-ультиматум про його подальшу заборону на випадок, коли він переростатиме рамки пісенного конкурсу ${ }^{31}$.

Найяскравіше реакцію комуністичної влади ілюструвала публікація в республіканській газеті “Правда Украины”, що побачила світ у жовтні 1989 р. Ї̈̈ кореспондент А. Федоров опублікував російськомовну статтю "Каким цветом расцвела “Червона Рута?”, передруковану чи не всією районною партійною пресою Чернівецької области. Автор стверджував, що буржуазний формат фестивалю гнівно обурив чернівчан, які спостерігали ходу львівських “глашатих" iз жовто-блакитними прапорами, тризубами, чорними хрестами, закликали “братися за вили” та відбирати зброю в силових структур. Наприкінці статті А. Федоров констатував: “Червона Рута" так і не розквітла в Чернівцях ${ }^{32}$.

Однак, ще під час конкурсу розтиражували фестивальні записи і їх відразу розкупили глядачі, а згодом і мешканці Чернівців у повному обсязі, що не задовільнило й десятої частини попиту. Згодом пісенний матеріял "Червоної Рути” копіювали десятки тисяч разів і швидко реалізовували у роздрібній мережі. Після фестивалю проведено загальноукраїнський пісенний тур. Звертає на себе увагу те, що 87 концертів лавреатів "Червоної Рути” відбувалися з небувалим успіхом у переповнених залах усієї УРСР. У подальшому фестивальні пісенні твори збирали великі авдиторії, які за кількістю могли порівнятися лише 3 проведенням політичних мітингів і страйків.

За іронією долі через кілька днів після завершення фестивалю першого секретаря ЦК КПУ В. Щербицького нарешті відправили у відставку. Відтак, 15 жовтня 1989 р. у Чернівцях НРУ, УГС та міський страйком на стадіоні “Буковин” провели багатотисячний мітинг під гаслом “'За демократичні вибори!", який після втручання міліції, яку очолював Г. Ястремський, перенесли на подвір'я ДЮСШ, що при вулиці Стасюка. Тут лунали вимоги припинити переслідувати Л. Сандуляка, прийняти альтернативні закони про вибори та мови, розкрити інформацію щодо алопеції, скасувати талони на харчі. Робітник ВО “Чернівцілегмаш" В. Тофій закликав НРУ брати владу в руки, асистент ЧДУ I. Нестерук - організовувати страйккоми, студент ЧДУ К. Бондаренко вимагав притягнути до кримінальної відповідальності першого секретаря обкому М. Нівалова. Піднято 7 українських і 3 єврейські національні прапори. Правоохоронці затримали виключеного з партії студента II курсу історичного факультету ЧДУ, члена УГС, засновника СУМБу С. Солтуса ${ }^{33}$.

${ }^{30}$ Андрей Федоров, “Каким цветом зацвела “Червона Рута”?”, Правда Украины, №10, (1989), 4.

${ }^{31}$ Інтерв'ю В. Старика записане 21. 07. 2010. (Особистий архів автора).

32 Андрей Федоров, “Каким цветом зацвела “Червона Рута”?”, Правда Украины, № 10, (1989), 4.

${ }^{33}$ Центральний комітет Компартії України, ЦДАГОУ, ф. 1, оп. 2, спр. 1033, арк. 24. 
ISSN 2078-6077. Наукові зошити історичного факультету Львівського університету. 2020. Випуск 21. Proceedings of History Faculty of Lviv University. 2020. Issue 21.

Як наслідок, 17 жовтня керівників цієї акції громадської непокори заарештували. Голова Ленінського райсуду Т. Сабов притягнув до відповідальности В. Старика, К. Бондаренка, О. Панчука, І. Кравчука, I. Кострицького, В. Тофія. У відповідь 19 жовтня біля приміщення міськвиконкому НРУ провів скеровану проти політичних переслідувань демонстрацію, де було затримано ще п'ятьох мітингувальників. Тому 20 жовтня розпочалося безстрокове голодування на знак протесту проти компартійного свавілля, яке набрало таких масштабів, що 21-22 жовтня партійна влада звільнила усіх політв'язнів. Дня 26 жовтня проведено загальноміський страйк, 29 жовтня під егідою НРУ, УГС, ТУМу відбувся п'ятитисячний мітинг у приміщенні Музею народної архітектури і побуту, де підняли українські, білоруські, молдовські, румунські, єврейські національні прапори. Тут було утворено “Асоціяцію виборців”, що мала намір не допустити компанійного втручання у вибори до Верховної та місцевих рад УРСР, призначених на березень 1990 р. ${ }^{34}$ Завершився рік тим, що 17 грудня у Вижниці пройшов мітинг, який провели активісти НРУ та УГС В. Клим та В. Кузьмін, які закликали до непокори органам компартійної влади. Дня 24 грудня на демонстрації в Чернівцях лунали вимоги відставки членів бюро обкому та міськкому у повному складі ${ }^{35}$.

Отже, в політичному контексті вперше за сорок п’ять років комуністичного панування на Буковині патріотично налаштована молодь краю, за підтримки національних сил Галичини, масово виявила непокору комуністичному режиму під час проведення пісенного конкурсу “Червона Рута” у вересні 1989 р. Це дозволяє констатувати, що загальнодемократичні перебудовні вимоги переросли в національно-визвольний рух антикомуністичного штибу на основі політизації неформальних груп, яка й спричинила утворення національних партій. Через рік саме вони стануть підгрунтям парламентського позбавлення влади КПРС-КПУ у Чернівцях та в цілому на Буковині.

У митецькому річищі відбувся ренесанс вітчизняної естрадної культури, що увільнялася від московського впливу. Відтепер молодь почала захоплюватися пісенною творчістю українських самодіяльних виконавців, які не входили до прокомуністичних мистецьких спілок, а відтак не продукували російської світоглядної ментальности. Це активізувало іiі патріотизм і реанімувало притуплене комуністами відчуття причетности до української національної культури.

\footnotetext{
34 Чернівецький обком Компартії України, ДАЧО, ф. 1, оп. 60, спр. 210, арк. 22.

${ }^{35}$ Буковинський Вісник, № 11, (1989), 1.

${ }^{36}$ Там само.
} 


\title{
FESTIVAL "CHERVONA RUTA" 1989 IN THE VISION OF CHERNIVTSI PARTY APPARATUS
}

\author{
Vasyl CHURA \\ Ivan Franko National University of Lviv \\ Department of Local History \\ 1, Universytetska str., Lviv 79000, Ukraine \\ e-mail: vchbox@ukr.net
}

The Soviet production model of the USSR imagined by the communists caused permanent decrease of citizens' income. Consequently, the growing economic crisis became obvious, which could deprive the ruling Communist Party monopoly on political power. So at the beginning of the second half of the 1980s. Communist party leadership decided to partially reform the economy. This "redecoration" was not supposed to touch the determining ground of economic complex - the means of production public ownership. It was about the planned economy hybridization with the key elements of the marketproduction self-sufficiency.

However, during 1985-1987 fragmentary implementation of certain elements of the market in the form of cost accounting and self-financing caused a rapid deterioration of the USSR inhabitants welfare. Therefore, the problem of political reform emerged as an objective necessity. Fundamental principles of the Communist Party democratization got publicity in the report of its initiator - M. Gorbachev. It was about the state of the perestroika policy implementation, initiated at XXVII Congress of the CPSU, which took place two years earlier - February 25, 1986. The political reform softened the intolerance of Communist party apparatus to the alternative points of view, revived inert environment of ordinary communists, started the overcome of atrophied communist dogma, and most importantly, was a key factor in the democratization of stagnant Soviet society and Communist Party country core. However, the property of the general public became a numerous past Communist Party misdeeds, which the party strongly renounced, referring to the Stalinist totalitarianism.

However, the implementation of political reforms not only blurred the foundation of the Communist Party monopoly, but also revived the growth of the national democratic movement, especially in regions that became part of the Soviet Union the latest. One of them was Bukovyna, where national liberation past has not been erased from people's memory. Rapid deployment of general democratic requirements led to the formation of informal groups that together with the councils of labor were the first who escaped from the party command. Politicization of amateur environment pave the way to the formation of national societies that were precursors of political parties.

Significant role in the transformation of the informal national environment of the independent Ukrainian politicum was played by artistic events, prominent place among which belonged to the song contest "Chervona Ruta" held in Chernivtsi in September 1989. Being in the format of perestroika innovations Chernivtsi party apparatus had favorable attitude to the competition, tried to head it and bring in a communist direction, hoping that it would demonstrate the Moscow leadership.

However, the secret Communist Party document showed that in fact Chernivtsi Communist authorities were hostile to any expression of Ukrainian national culture. So Chernivtsi party leadership has done everything to ensure that the festival was another proof of its allegiance to the Union's Central Committee and thus was held according to the Communist Party script. However, political reform in the USSR and administrative - in the CPSU continued to weaken the monolithic communist ranks and blurred the foundations of its regional authorities. Against this background, Bukovina national democratic forces, with the Galician informal support managed to convert song contest "Chervona Ruta" into a massive manifestation of civil disobedience with distinct Ukrainian national basis. 
ISSN 2078-6077. Наукові зошити історичного факультету Львівського університету. 2020. Випуск 21. Proceedings of History Faculty of Lviv University. 2020. Issue 21.

Despite the Communist Party opposition, the festival significantly revived the deployment of the national movement, which ultimately led to the formation of political parties, that enabled the Chernivtsi Communist Party power failure in 1990 and Ukrainian state independence re-establishment in 1991.

Keywords: perestroika, the Communist party apparatus, informal association, national and cultural revival, music festival "Chervona Ruta", resistance.

\section{REFERENCES}

Baran Volodymyr. Ukraine: modern history (1945-1991), Lviv: Ukrainian Institute of I. Krypyakevych NAS of Ukraine, 2003. (in Ukrainian)

Bukovynskiy Journal, No.11, (1989): 1. (in Ukrainian)

Chernivtsi Regional Committee of the Communist Party of Ukraine, State Archive of Chernivtsi region, Fond 1, Series 60, File 154, Sheet 13. (in Ukrainian)

Chernivtsi Regional Committee of the Communist Party of Ukraine, State Archive of Chernivtsi region, Fond 1, Series 60, File 163, Sheet 14. (in Ukrainian)

Chernivtsi Regional Committee of the Communist Party of Ukraine, State Archive of Chernivtsi region, Fond 1, Series 60, File 210, Sheet 87. (in Ukrainian)

Chernivtsi Regional Committee of the Communist Party of Ukraine, State Archive of Chernivtsi region, Fond 1, Series 60, File 211, Sheet 14. (in Ukrainian)

Chernivtsi Regional Committee of the Communist Party of Ukraine, State Archive of Chernivtsi region, Fond 1, Series 60, File 226, Sheet 48-53. (in Ukrainian)

Chernivtsi Regional Committee of the Communist Party of Ukraine, State Archive of Chernivtsi region, Fond 1, Series 60, File 314, Sheet 25. (in Ukrainian)

Central Committee of Communist Party of Ukraine, Central State Archive of Public Organizations of Ukraine, Fond 1, Series 2, File 1033, Sheet 24. (in Ukrainian)

Fedorov, Andriy, "What color is "Chervona Ruta" blossoming?", The truth of Ukraine, No.10, (1989): 4. (in Ukrainian)

Interview recorded wiht Volodymyr Staryk 21. 07. 2010. (Personal archive of the author).

Bukovynskiy Journal, No.10, (1989): 3. (in Ukrainian)

Kobuta, Stepan, "Informalo non-governmental organization in the years 1987-1989 as precursors ukrainian political movement" in The Scientific Issues of Ternopil Volodymyr Hnatiuk National Pedagogical University. Series: History, (Ternopil, 2008). (in Ukrainian)

Kulchytskiy, Stanislav, Historical background of escalating restructuring of the national revolution (1989-1991) in Ukrainian History Problems: facts, opinions, search, (Lviv, 2001). (in Ukrainian)

Panchuk, Oleg, "Ruch and election”, Bukovynskiy Journal, No. 12, (1989): 3. (in Ukrainian)

Lepsha, Ivan, "This is the clean water", Youth Ukraine, No. 12, (1987): 3. (in Ukrainian)

Literary Ukraine, No. 2, (1989): 3. (in Ukrainian)

Muravskiy, Oleg, Western Ukraine lands: The Road to Independence (1985-1991)), (Lviv: Ukrainian Institute of I. Krypyakevych NAS of Ukraine, 2011). (in Ukrainian)

Kurnitskyy, Olexander, "Native word”, Bukovynskiy Journal, No. 10, (1989): 1. (in Ukrainian)

Seko, Jaroslav, Illegal organization of USSR the second half of the twentieth century: general description in Ukraine-Europe-World The International Collection of Scientific Works. Series: History, International Relation, (Ternopil, 2012). (in Ukrainian)

Taran, Hryhoriy, “About Ukrainian symbols”, Flag of Victory, No. 8, (1989): 2. (in Ukrainian) 